\title{
Trading support method based on computational intelligence for speculators in the options market
}

\author{
Nijolè Maknickienè \\ Department of Financial Engineering, Faculty of Business \\ Management, Vilnius Gediminas Technical University, \\ Lithuania \\ nijole.maknickiene@,vgtu.lt \\ ORCID 0000-0003-2785-5183
}

\author{
Algirdas Maknickas \\ Faculty of Mechanics, Research Laboratory of Numerical Simulations, \\ Vilnius Gediminas Technical University, \\ Lithuania \\ algirdas.maknickas@vgtu.lt \\ ORCID 0000-0002-8431-2292
}

Raimonda Martinkutè-Kaulienè

Department of Financial Engineering, Faculty of Business

Management, Vilnius Gediminas Technical University,

Lithuania

r.martinkute-kauliene@,vgtu.lt

ORCID 0000-0003-4231-5003

Abstract. The financial world has changed dramatically in recent decades. Electronic data processing, globalisation, and deregulation have changed markets, and the biggest part of these major changes includes derivatives. As financial markets become more interconnected and global, volatility in these markets may increase dramatically in the future. It is natural that the derivatives market is gaining attention and popularity among market participants as an alternative to traditional investment and speculative instruments. The growing number of technologydriven applications and innovations in the financial sector encourages the inclusion of products relating to automated trading and robotic advice in financial decision-making. The aim of this paper is to investigate different option-trading strategies and to evaluate the effect of computational intelligence on trading success in the derivatives markets. The recurrent neural network (RNN) Keras was adopted for forecasting option prices, and the results were compared with the forecasting using the evolution of recurrent systems with optimal linear output algorithms (EVOLINO) for RNNs. This forecasting

Received: January, 2020 1st Revision:

July, 2020

Accepted: September, 2020

DOI:

$10.14254 / 2071$ 8330.2020/13-3/15 
tool was investigated as a support system for speculators in the options market. The proposed method helps speculators select an appropriate option-trading strategy and increases the probability of profit. The values of trading according to the information from the tools of computational intelligence proved that the proposed method is useful, although trading in options is still very risky.

Keywords: derivatives, financial engineering, investor, artificial intelligence, deep learning, probability, strategy.

JEL Classification: G0, G1, C6, O16

\section{INTRODUCTION}

Under conditions of globalization and uncertainty, financial markets are playing a very important role. The possibility to use qualitative information and make decisions faster than other market participants is crucial at today's financial markets. During the past two decades, financial markets were affected by market deregulation, growing trade worldwide, and technological development. Increased market volatility was the reason for the growing demand for risk management products and tools. For this reason, the derivatives market became a significant part of the financial system. If the derivatives market is functioning well, market participants can share risks efficiently, earn profits, and boost economic growth. A well-functioning derivatives market is an information channel that reflects equilibrium prices and helps making the right decisions (Vo et al., 2018). Methods of estimation for risk-function to identify objective and risk-neutral parameters are important determinants in market option trading (Wu et al., 2019; Kotaskova et al., 2020).

The growth in the number of Internet users inspired the growth of electronic Internet-based trading of securities and the growth of digital trading platforms. Digital trading opened new opportunities for economic activity of the financial market participants and leading services. The need to decrease and break down complex risks into distinct sources inspired the creation of new, non-traditional financial products. Increasingly, derivatives are included in the composition of an investment portfolio not only for banks and financial institutions but also for individual investors. Knowledge of trading strategies helps investors in making successful investment decisions. Despite the knowledge, rapidly changing conditions influence the decision-making of investors, so forecasting is significant in all steps of financial management. Forecasting can reduce uncertainty or may convert it into the probability of risk, which can be evaluated probabilistically. The ability to predict price volatility with greater precision is important for financial markets and for the whole economy. The derivatives market is not an exception. In this context, Civelek et al. (2019) and Cepel et al. (2019) showed in the case studies of the Czech Republic that potential users with more trust to local currencies have more tendencies to demand higher discount rates. The crisis of 2008 showed the importance of symmetric and asymmetric contagion shocks between the U.S. financial markets and other international markets (Kao et al., 2019).

A forecasting tool based on the recurrent neural network (RNN) Keras was adopted for predicting option prices in this research. The aim of this paper is to investigate different option-trading strategies and to value the effect of computational intelligence on trading success at derivatives markets. The results were compared with the forecasting results calculated by means of EVOLINO RNN. The proposed method helps speculators select an appropriate option-trading strategy and increases the probability of profit.

The rest of the manuscript is organized as follows. The first section of the article presents the introduction. The second section provides literature review. The third section describes the computational intelligence tool and the method of selecting option strategies using forecasts from this tool. The results of 
real-time testing of the proposed method using two different tools are presented in the fourth section. Conclusions and the references list complete the article

\section{LITERATURE REVIEW}

The derivatives market differs from other markets, primarily by the definition of the transaction time. These deals are not current, so they have not only new opportunities but also additional risks. Vashishtha and Kumar (2010) investigated the main applications of financial derivatives: management of risk, efficiency in trading, speculation, price discovery, and price stabilization, and they assessed the causes of the rapid growth of the Indian derivatives market. Kozarevic et al. (2011) concluded the opposite, stating that in the future there would be no need for establishing an organized derivatives market, as a market segment of stock exchanges in Bosnia Hercegovina, what would be a key limitation for further financial market development. Moments of future prices are important determinants on option markets and non-structural approach show potentials in estimating them (Šestanović et al, 2018). GARCH diffusion model proved to be valuable in estimating market prices risks according to the study of Wu et al. (2018).

Currently, the structure of the main derivatives market players is changing rapidly due to increasing market availability and globalisation. Hedgers, speculators, and arbitrageurs play a significant role as managers of basic and complex financial instruments and have the opportunity to change the landscape of the financial industry (Vashishtha \& Kumar, 2010).

Trang(2018) offered a slightly modified point of view: the usage of derivative products depends on the motives and perspectives of the users:

- End users, such as corporations and investment managers, use derivatives for speculation, risk management, cost reduction, or regulation avoidance.

- Market-makers, such as brokers, dealers, or intermediaries, buy from end users that sell at a lower price and sell to end users who buy at a higher price.

- Economic observers, for example, the National Bank, are responsible for regulations and general supervision of the market and economic environment.

Lange (2011) states that there are many active traders in the derivative markets. Corporations, financial institutions, farmers, and even national governments and agencies trade in the derivatives markets. The main reason of this activity typically is better to manage asset and liability portfolios, hedge financial market risk (Mentel et al., 2016, 2017), and minimize costs of capital funding (Lange \& Longitude, 2011; Bernal-Ponce, Castillo-Ramírez \& Venegas-Martínez, 2020).

In the global interest rate derivatives market, Meyer (2017) investigated the profitability patterns and their determinants. Especially high profitability was found in the bank sector. Regarding the determinants of the profitability of a trade, there are the counterparty type, market position, and trade currency. Because the main traders in the derivatives market are institutional investors, such as banks, primary insurance companies and reinsurers, corporate treasurers, hedge funds, and pension funds, the growth of the number of individual investors is now noticeable. Digital trading reduces the technical difference between institutional and individual investors. Li et al. (2018) investigated the differences between institutional and individual investors in the options market. They found that the main factor of profitability is their trading skills rather than their informational advantages, but institutional investors have more opportunities to take advantage of alternatives and therefore more often change the investment portfolio.

Despite all the offering advantages, derivatives are highly controversial, and Tan(2010) elaborated that derivatives in many cases are underestimated and receive negative sentiment because they are not used properly or because market participants do not understand how derivatives work in the markets. It is crucial to remember that higher risk does not necessarily bring a higher return, thus before engaging in any activity 
with derivatives, according to Bellalah(2008), there is a need to examine them because derivatives experience quite high risks.

Market participants with little capital are free to participate in derivatives trading, which leads to an increase in volatility and speculation. Derivatives have a leveraged nature, and often, market players do not evaluate their position adequately. This situation can lead to bankruptcy.

All types of investors in the derivatives market are faced with additional credit risk or risk of default of a corporation.Duffee and Zhou (2001) and Instefjord (2005) investigated risk management in banks, and Froot et al. (1993) and Bedendo and Colla (2015) investigated its use in corporations. Credit risk has inspired firms to coordinate investment plans and create hedging strategies and new financial instruments (Neal, 1996; Batta et al., 2016). New products, such as credit default swaps, cannot prevent event risk. The diversity of forecasting and portfolio formation models also creates a model risk for traders. Danielsson et al. (2016) explained the methods of the evaluation of model risk for models of forecasting financial instruments and market risk. This series of risk transfers among market players creates a particular flow of risk.D'Errico et al. (2018) investigated the counterparty risk between sellers, dealers (indirectly connected to each other), and risk buyers.

Researchers have paid attention to the liquidity and heterogeneity of the derivatives market. Thapa et al. (2016) stated that the ability to use derivatives can be limited by trading costs and liquidity. Le Grand and Ragot (2016) examined the differences in options trading in incomplete and complete markets. Jarrow (2018) researched the pricing of derivatives in an incomplete market. The problems of efficiency in the finance market with more derivative instruments circulating are also interesting to researchers. DaDalt et al. (2002) found that corporations that include derivatives in their investment portfolios decrease the level of asymmetric information. Chung et al. (2017) found that active trading by foreign investors tends to exacerbate informational variation. Borg (2015) and Godwin et al. (2017) examined the role of financial politics in the derivatives market. Harada et al. (2016) found that the regulation of the derivatives markets has a relationship with financial crises. Zelenko (2017) explained the primary aspects of the regulation and role of the derivatives markets in financial crises.

Information technologies, digitalisation, and computational intelligence penetrate into all areas of life and into many lines of business (e.g. tourism - Štefko et. al., 2020) Financial markets have always been a leader in technology applications. The financial data of various instruments are forecasted using artificial intelligence on the basis of Long Short-term Memory (LSTM) (Cao ey al. 2019, Bukhari et al. 2020, Livieris et al. 2020), Gated Recurrent Unit (GRU) (Wu et al. 2019, Munkhdalai et al. 2020 ), and the comparison of the forecasting accuracy of both these instruments with the popular ARMA is presented by Yamak et al. 2019. The application of computational intelligence in the derivatives market is also interesting for researchers. Yao et al. (2000) compared the Black-Scholes model and the neural network model. Wu (2004) proposed the application of the fuzzy sets theory to the Black-Scholes formula. King et al. (2005) researched the simulation of the derivatives market using an agent system. Moreover, Huang (2008) examined the forecasting of online options using a hybrid model based on the Kalman filter and support vector machines. Non-linear financial instruments, such as options, must be predicted using non-linear tools, such as those in the proposed hybrid model. A high accuracy of forecasting has been achieved in terms of three types of options.Yang et al. (2017) proposed a model based on neural networks for option pricing that outperforms the existing learning-based and some econometric alternatives.

Successful trading strategies in the derivatives market include good data mining, accurate forecasting tools, robust portfolio selection rules, and insightful investor's behaviour (if robots do not replace the person).Muck (2010) investigated trading strategies based on investment portfolio construction and the potential benefit and change of risk from adding derivatives to the market. Chang and Tian (2015) investigated option-trading strategies with the Bayesian network with the aim to create strategies for 
investment decisions. The Bayesian network is constructed from both historical data and the domain knowledge of several relevant financial factors. The investment strategies proposed by the authors are typically more concerned with market fundamentals, which can ride out the downtrends and short-term market fluctuations. Ucar et al. (2015) investigated option-trading strategies used genetic algorithms and particle swarm optimisation and obtained good results in comparison to the buy and hold strategy. The bull call spread option strategy and bear put spread option strategy performed better than the basic buy and hold strategy and other models while keeping the risk at an acceptable level. Blanco and Wehrheim (2017) researched how financial derivatives affect managerial investment decisions in the real economy and found that firms with greater option-trading activity pursue more creative, diverse, and risky innovation strategies. The research was completed by examining the relationship between the equity option markets and the standard measures of firm innovation.

In this research, different option strategies using the Python deep learning library, Keras, were investigated in a real-time demo platform. It was compared with data predicted using the EVOLINO RNN.

\section{METHODOLOGICAL APPROACH}

The trading platform used in the current research was developed using the RNN of long short-term memory (LSTM) neural cells, where LSTM is the RNN architecture that has input, output, and forget gates. Hochreiter and Schmidhuber (1997) presented a detailed description of LSTM working principles (Fig. 1).

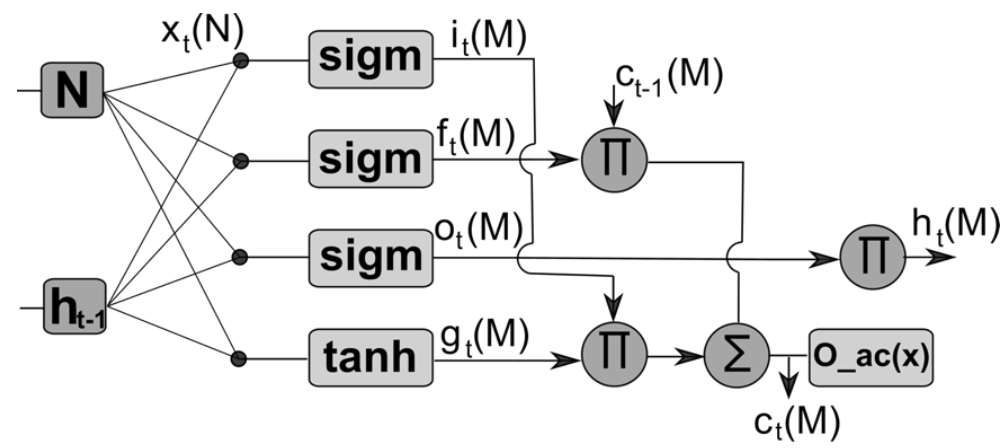

Figure 1. Long short-term memory (LSTM)

Source: own evaluation.

Here $i_{t}(M), f_{t}(M), o_{t}(M), g_{t}(M), h_{t}(M)$ are expressed as follow:

$$
\begin{gathered}
i_{t}=\sigma\left(x_{t} W_{x i}+h_{t-1} W_{h i}+b_{i}\right) \\
f_{t}=\sigma\left(x_{t} W_{x f}+h_{t-1} W_{h f}+b_{f}\right) \\
o_{t}=\sigma\left(x_{t} W_{x o}+h_{t-1} W_{h o}+b_{o}\right) \\
g_{t}=\sigma\left(x_{t} W_{x g}+h_{t-1} W_{h g}+b_{g}\right) \\
h_{t}=o_{-} a c t\left(c_{t}\right),
\end{gathered}
$$

where $x_{t}$ is frame $\mathrm{t}$ in input sequence, $h_{t}$ is cell output for frame $\mathrm{t}$ input sequence, $g_{t}$ is new cell candidates for frame $t$ in input sequence, $c_{t}$ is cell state for frame $t$ in input sequence, $W_{* *}$ are weights for appropriate input sequence, $b_{*}$ are bias for appropriate input sequence, $\sigma$ sigmoid activation function, tanh tangent hyperbolic activation function, $o_{a c}$ linear output activation function.

The predictive RNN was formed by the appropriate interconnected LSTM cells with input, hidden LSTM, dropout, and output layers. The input layer consists of 100 inputs for the daily data of exchange 
rates, and the same number of additional inputs of gold vs US dollar daily prices, where the additional input vector enables a better convergence of the predictive RNN, where LSTM cells was connected by using many to one LSTM connection method (Fig. 2).

The LSTM neural cells were chosen for predicting the neural network in the case of the possibility to correct the prediction of the Mackey-Glass recurrent process (Junges and Gallas, 2012). On the other hand, the dropout layer randomises the number of connections between layers, and this property was used to obtain an output layer without additionally calculating the whole probability density function values of each exchange rate prediction. Schmidhuber et al. (2005) proposed the forecasting tool 'Evolution of recurrent systems with Optimal Linear Output' (EVOLINO), which was adopted to predict exchange rates. Maknickiene and Maknickas (2016) and Stankevičiene et al. (2014) investigated the support system for investors in the exchange market (Maknickas and Maknickiene, 2019). With the emergence of a new class of artificial intelligence algorithms, a predictive RNN implementation using the deep learning library Keras interfaced (Chollet et al., 2015) with the TensorFlow (Abadi et al., 2015) neural network framework was proposed. Therefore, the optimisation of neural network weights was achieved using Adam, which derives from the 'adaptive moments' (Kingma and Ba, 2015) deep learning optimisation algorithm, which is part of the Keras software and allows the possibility of using the NVIDIA graphics processing unit (GPU) to shorten the optimisation time of the developed neural network. In our calculations, we used GeForce GTX 1080 Ti GPU.

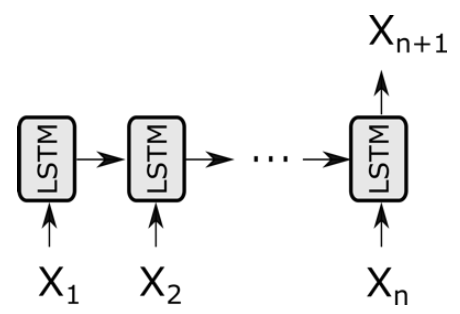

Figure 2. LSTM many to one connection method

Source: own evaluation.

The results of the prediction are a combination of the distributions of the expected values. This prediction provides considerable opportunities for researching option-volatility strategies. We introduced a limitation in that the strike switches profit/loss states over the strike price but does not change the combination of the statuses. In addition, inaccuracy arises because the option buy/sell decision is not made at the close of the market.

The simplest option strategies are named naked strategies, and they consist of one transaction: a call if the prediction shows increasing prices (Fig. 3) and a put if the prediction shows decreasing prices for the financial instrument (Fig. 4). 


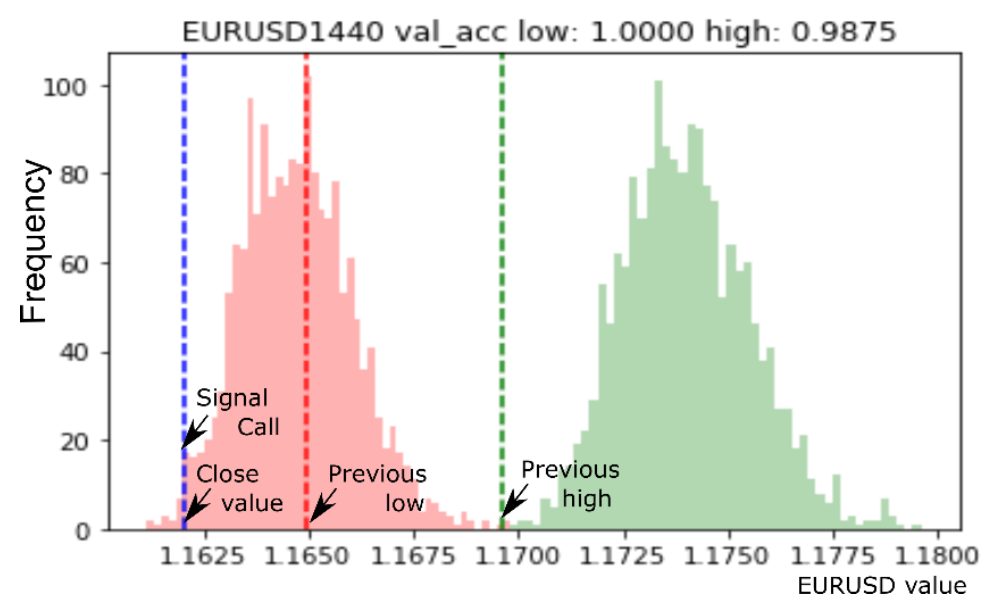

Figure 3. Example of the signal for a naked strategy call

Source: own evaluation.

The probability of success depends on the accuracy of the forecasting tool Keras in our research. Both distributions are to the right of the closing value shown by the blue line. To the left of the blue line (Fig. 3) is the area of loss and to the right of the blue line is the area of profit when the decision is a call. The probabilities of profit and loss are calculated from the plots of the distributions to the left and right of the blue line. The profit from a single call option is denoted by $P_{\text {call }}(N+)$, andloss is denoted by $L_{\text {call }}(N-)$. The previous low and high values use a starting point for determining the direction of the price movement.

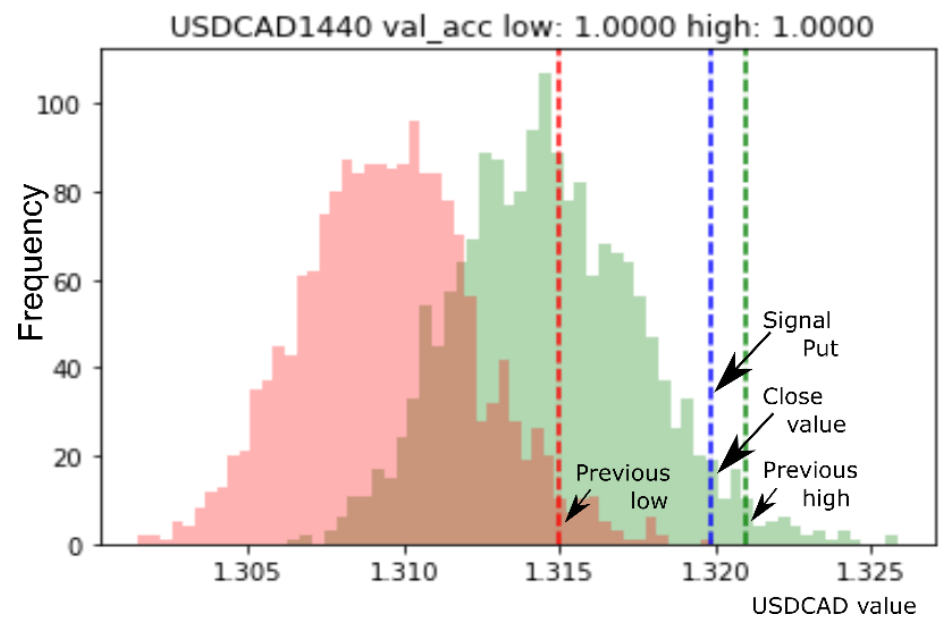

Figure 4. Example of the signal for the naked strategy put

Source: own evaluation.

The naked strategy put is the opposite of the naked call, with the profit, $P_{p u t}$, resulting in an $N+$ market and the loss, $L_{p u t}$, resulting in an $N$ - market. The decision to choose a put comes from the prediction distributions. They are left of the closing value (Fig. 4, blue line).

These strategies consist of two opposite transactions for the same asset. These are risk management strategies that investors can use to guard against the loss of unrealised gains. 


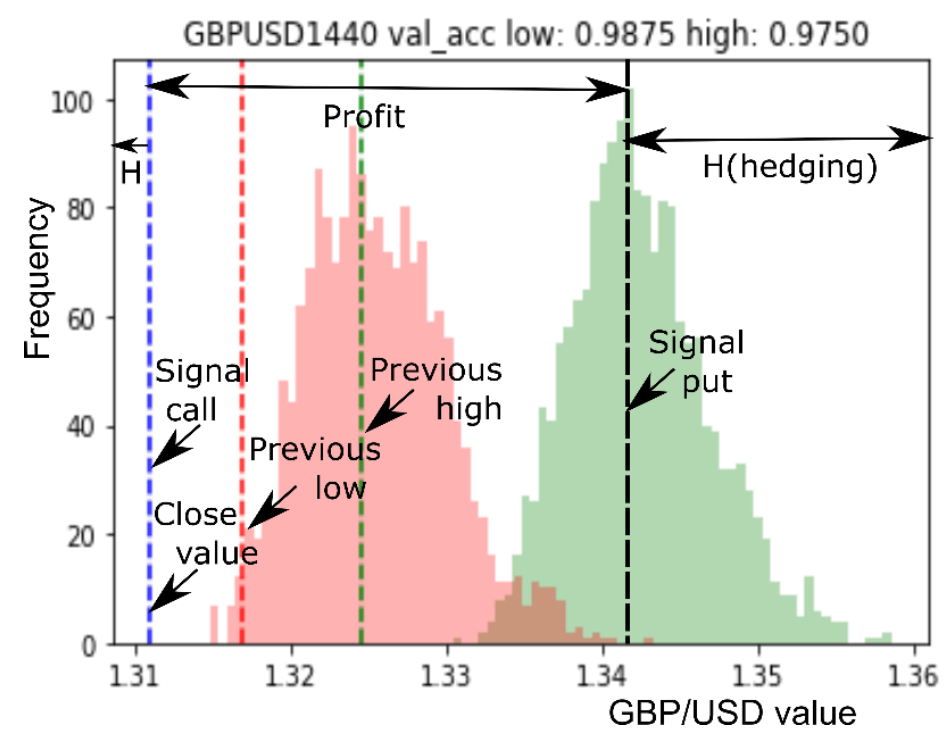

Figure 5. Example of an insured strategy

Source: own evaluation.

The first decision is making a prediction by evaluating the position of the distributions in relation to the closing value (Fig. 5 blue line), as in the case of the naked strategy. Forecasting by Keras (Fig. 5) allows us to use distributions to obtain the opposite signal. The main mode of high-value distributions is using a put signal, and for low-value distributions, the main mode is the call signal. The opposite transaction creates three different opportunities for the final result: an insured profit left of the blue line $\left(L_{\text {call }}+P_{p u t}\right)$, a high profit between the blue line and black line created on the point of high distribution $\left(P_{\text {call }}+P_{\text {put }}\right)$, and an insured profit to the right of the black line $\left(P_{\text {call }}+L_{p u t}\right)$. All these strategies have a result marked of $\mathrm{C}+$.

Options strategies based on market sentiment reflect the investors' expectations about the market state: bullish, bearish, or neutral (non-directional). The strategy consists of three or more transactions.

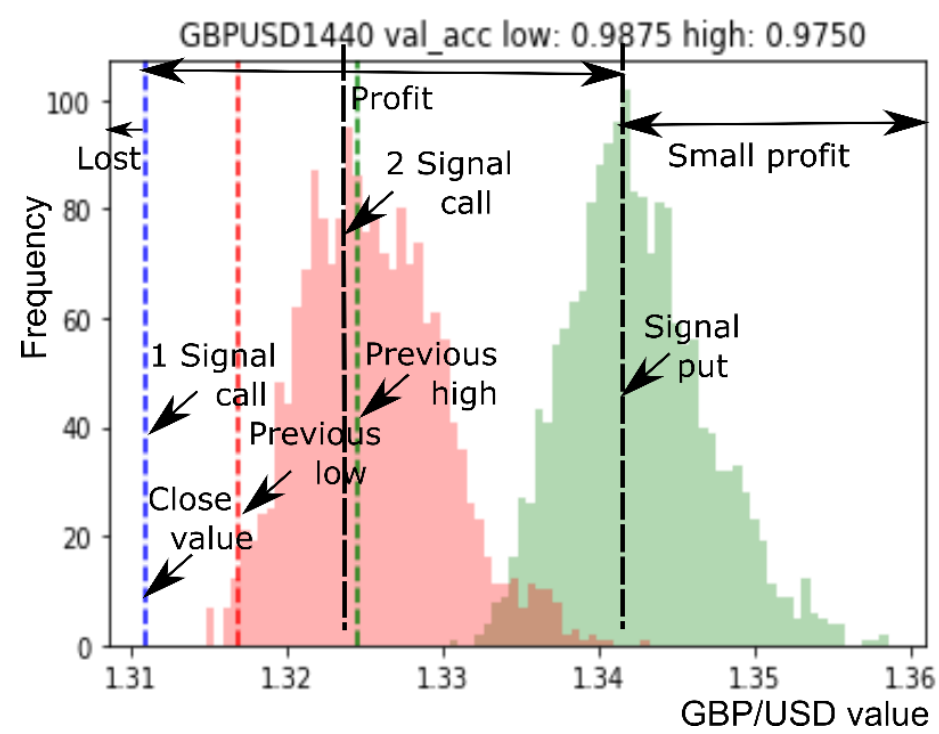

Figure 6. Example of a bullish market strategy

Source: own evaluation. 
The bullish market strategy is called strip and consists of two call options and one put. The first decision is made by evaluating the closing value and the position of the high and low distributions (Fig. 6). The signals for the second and third options are determined by the modes of the high and low distributions. The opportunities for profit or loss can be described using the following four states:

- $\left(L_{1 \text { call }}+L_{2 \text { call }}+P_{\text {put }}\right)<0(2 L P-)$,

- $\left(P_{1 \text { call }}+L_{2 \text { call }}+P_{\text {put }}\right)>0(2 P L+)$,

- $\left(P_{1 \text { call }}+P_{2 \text { call }}+P_{\text {put }}\right)>0(3 P+)$, and

- $\left(P_{1 \text { call }}+P_{2 \text { call }}+L_{\text {put }}\right)>0(2 P L+)$.

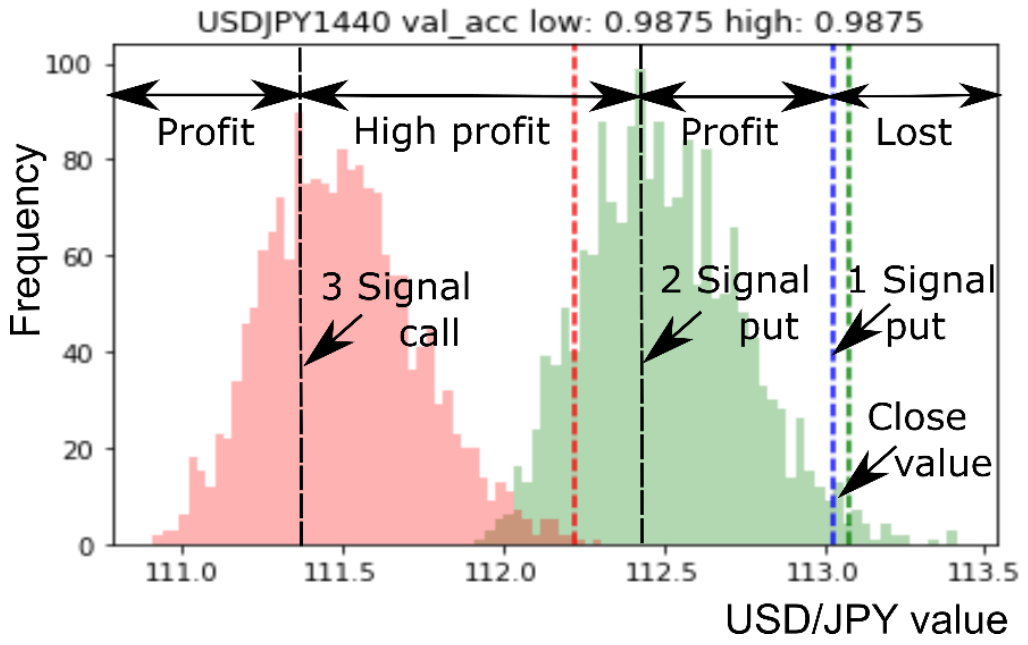

Figure 7. Example of a bearish market strategy

Source: own evaluation.

The bearish market strategy, called the strap strategy, is opposite the bullish market strategy (Fig.7). The final result can be described in the following four states:

- $\left(\mathrm{P}_{1 \text { put }}+\mathrm{P}_{2 \text { put }}+\mathrm{L}_{\text {call }}\right)>0(2 \mathrm{PL}+)$,

- $\left(\mathrm{P}_{1 \text { put }}+\mathrm{P}_{2 \text { put }}+\mathrm{P}_{\text {call }}\right)>0(3 \mathrm{P}+)$,

- $\left(\mathrm{P}_{1 \text { put }}+\mathrm{L}_{2 \text { put }}+\mathrm{P}_{\text {call }}\right)>0(2 \mathrm{PL}+)$, and

- $\left(\mathrm{L}_{1 \text { put }}+\mathrm{L}_{2 \text { put }}+\mathrm{P}_{\text {call }}\right)<0$ (2LP-). 


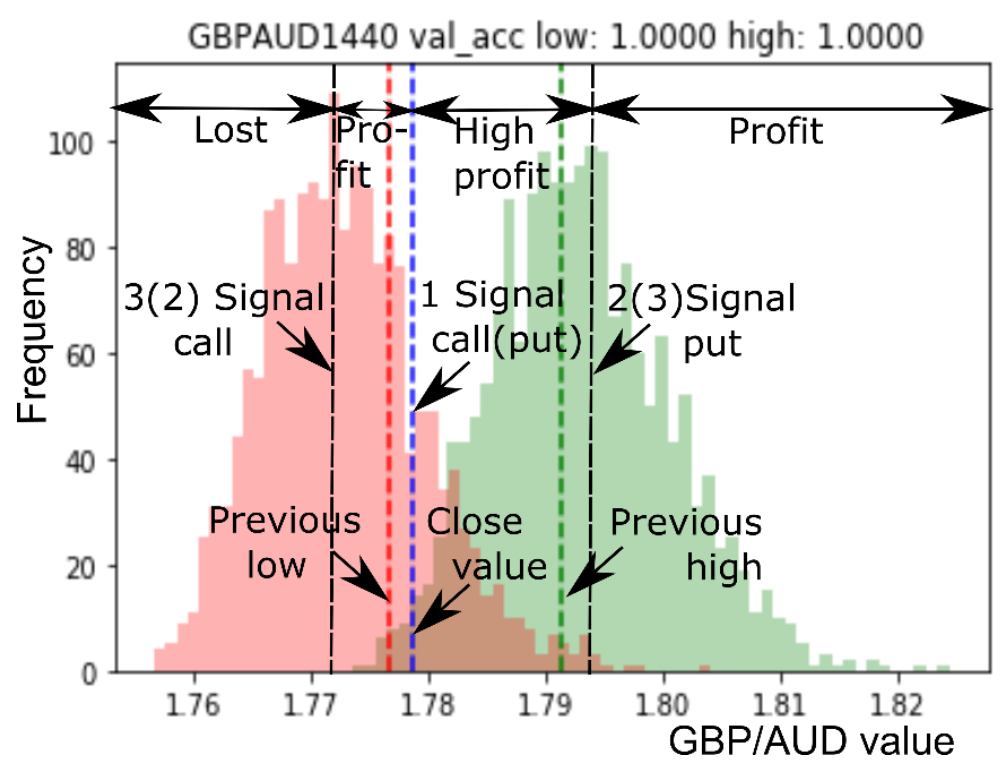

Figure 8. Example of a neutral strategy collar

Source: own evaluation.

When the market has no clear direction (Fig. 8), we can use the collar strategy, which consists of three signals. The first decision is to choose a call or put option. The second option is determined by the first achieved mode of distribution: high distribution - put, low distribution - call, and the next option is the opposite of the second option. The final results can be described as follows:

- $\left(\mathrm{L}_{1 \text { call }}+\mathrm{P}_{2 \text { put }}+\mathrm{L}_{3 \text { call }}<0\right.$ (2LP-),

- $\left(\mathrm{L}_{1 \text { put }}+\mathrm{P}_{2 \text { put }}+\mathrm{P}_{3 \text { call }}>0(2 \mathrm{PL}+)\right.$,

- $\left(\mathrm{P}_{1 \text { call }}+\mathrm{P}_{2 \text { put }}+\mathrm{P}_{3 \text { call }}\right)>0(3 \mathrm{P}+)$, and

- $\left(\mathrm{P}_{1 \text { call }}+\mathrm{L}_{2 \text { put }}+\mathrm{P}_{3 \text { call }}>0(2 \mathrm{PL}+)\right.$.

The described strategies have more profitable states than loss states. If the forecasting was not right, the trading decisions also are determined by the forecasting distributions.

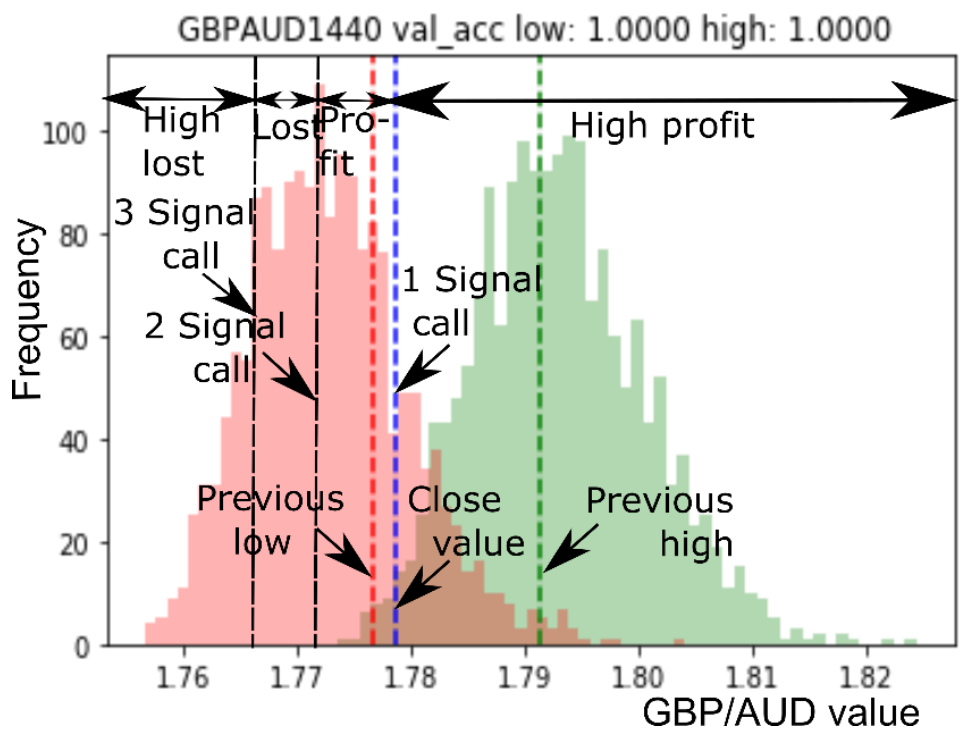

Figure 9. Example of the strategy when the prediction is not right

Source: own evaluation. 
An example of the strategy when the prediction is not right is presented in Fig. 9. The first decision according to the closing value and the high or low distributions was a call, but the price decreased. Thus, the second decision must be a call on the mode of low distribution. If the price again falls, the next decision will again be a call. The following four states result:

- $\left(\mathrm{L}_{1 \text { call }}+\mathrm{L}_{2 \text { call }}+\mathrm{L}_{3 \text { call }}\right)<0$ (3L-),

- $\left(\mathrm{L}_{1 \text { call }}+\mathrm{L}_{2 \text { call }}+\mathrm{P}_{3 \text { call }}\right)<0$ (2LP-),

- $\left(\mathrm{L}_{1 \text { call }}+\mathrm{P}_{2 \text { call }}+\mathrm{P}_{3 \text { call }}>0(2 \mathrm{PL}+)\right.$, and

- $\left(\mathrm{P}_{1 \text { call }}+\mathrm{P}_{2 \text { call }}+\mathrm{P}_{3 \text { call }}>0\right.$ (3P).

An opposite example of the strategy when the prediction is not right is shown in Fig. 10.

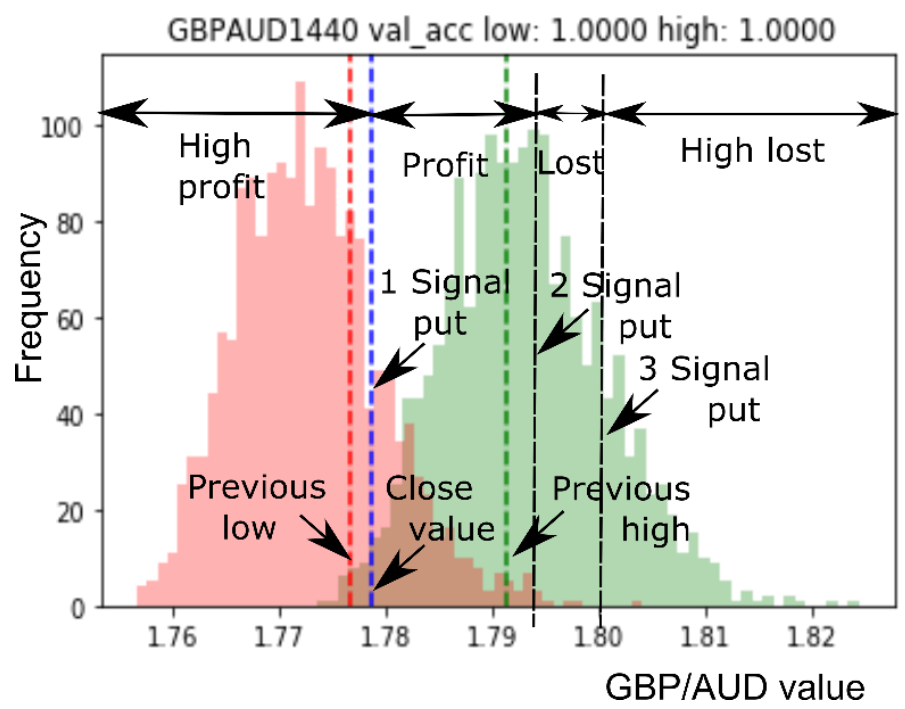

Figure 10. Example of a strategy when the prediction is not right (opposite)

Source: own evaluation.

The following are the states of the result:

- $\left(\mathrm{P}_{1 \text { put }}+\mathrm{P}_{2 \text { put }}+\mathrm{P}_{3 \text { put }}\right)>0(3 \mathrm{P}+)$,

- $\left(\mathrm{L}_{1 \text { put }}+\mathrm{P}_{2 \text { put }}+\mathrm{P}_{3 \text { put }}\right)>0(2 \mathrm{PL}+)$,

- $\left(\mathrm{L}_{1 \text { put }}+\mathrm{L}_{2 \text { put }}+\mathrm{P}_{3 \text { put }}\right)<0$ (2LP-), and

- $\left(\mathrm{L}_{1 \text { put }}+\mathrm{L}_{2 \text { put }}+\mathrm{L}_{3 \text { put }}<0\right.$ (3L-).

Other decisions (put, put, and call) give less probability of profit.

The success of the option-trading strategies depends on the accuracy of the forecasting tool. A good prediction tool creates a high value. The second problem is the trader's behaviour; overconfidence, low confidence, loss aversion, anchoring, and other biases can be reduced by creating trading robots.

\section{EMPIRICAL RESULTS AND DISCUSSION}

The testing of the strategies conducted on a real-time platform using two different accounts:

- Predictions of eight exchange rates were made using the EVOLINO RNN (evolize.com) in London time. The calculation time for one exchange rate high and low data is 45 minutes. Immediately after obtaining the predictions, the first transaction is made with each exchange rate (call or put). Subsequent transactions are made depending on the situation. 
- Predictions of 10 exchange rates were made using Keras. The calculation time for one exchange rate high and low data is 3 minutes. The option market decisions are made in the same way.

All options have an equal investment amount and some maturity time at the end of the trading day. Table 1 presents the daily trading decisions and daily results when the prediction was made using EVOLINO. Over the nine days, there were $32(44 \%)$ losses and $40(56 \%)$ profits.

Table 1

Trading strategies when predictions were made using evolize.com.

\begin{tabular}{|l|l|l|l|l|l|l|l|l|l|}
\hline Exchange rate $\backslash$ trading days & 1 & 2 & 3 & 4 & 5 & 6 & 7 & 8 & 9 \\
\hline EUR/USD & $2 \mathrm{LP}-$ & $\mathrm{C}+$ & $\mathrm{C}+$ & $3 \mathrm{P}+$ & $\mathrm{C}+$ & $\mathrm{C}+$ & $\mathrm{C}+$ & $3 \mathrm{~L}-$ & $2 \mathrm{LP}-$ \\
\hline GBP/USD & $\mathrm{N}-$ & $\mathrm{N}+$ & $\mathrm{N}-$ & $\mathrm{N}-$ & $\mathrm{N}-$ & $\mathrm{N}+$ & $3 \mathrm{~L}-$ & $\mathrm{N}-$ & $\mathrm{N}-$ \\
\hline USD/CHF & $2 \mathrm{LP}-$ & $\mathrm{C}+$ & $2 \mathrm{Pl}+$ & $2 \mathrm{PL}+$ & $\mathrm{N}-$ & $\mathrm{C}+$ & $2 \mathrm{LP}-$ & $3 \mathrm{~L}-$ & $\mathrm{N}-$ \\
\hline USD/JPY & $\mathrm{C}+$ & $\mathrm{N}+$ & $3 \mathrm{P}+$ & $\mathrm{N}+$ & $2 \mathrm{PL}+$ & $\mathrm{N}+$ & $\mathrm{C}+$ & $2 \mathrm{LP}-$ & $2 \mathrm{PL}+$ \\
\hline USD/CAD & $2 \mathrm{LP}-$ & $\mathrm{N}-$ & $\mathrm{C}+$ & $\mathrm{C}+$ & $\mathrm{N}+$ & $2 \mathrm{PL}+$ & $\mathrm{N}+$ & $2 \mathrm{PL}+$ & $\mathrm{N}-$ \\
\hline EUR/JPY & $\mathrm{N}+$ & $\mathrm{N}+$ & $\mathrm{N}-$ & $\mathrm{N}-$ & $\mathrm{N}+$ & $3 \mathrm{~L}-$ & $\mathrm{N}+$ & $\mathrm{N}+$ & $\mathrm{N}-$ \\
\hline AUD/USD & $2 \mathrm{LP}-$ & $\mathrm{C}+$ & $\mathrm{N}+$ & $\mathrm{C}+$ & $2 \mathrm{LP}-$ & $\mathrm{N}+$ & $2 \mathrm{PL}+$ & $\mathrm{N}+$ & $2 \mathrm{LP}-$ \\
\hline EUR/GBP & $2 \mathrm{LP}-$ & $2 \mathrm{LP}-$ & $\mathrm{N}+$ & $\mathrm{N}+$ & $\mathrm{N}-$ & $2 \mathrm{LP}-$ & $\mathrm{N}-$ & $\mathrm{N}+$ & $\mathrm{N}-$ \\
\hline
\end{tabular}

Table 2 presents the daily trading decisions and results when predictions were made using Keras. Within 10 days, there were $28 \%$ losses and $72 \%$ profitable transactions.

Trading strategies when predictions were made using Keras

\begin{tabular}{|l|l|l|l|l|l|l|l|l|l|l|}
\hline Exchange rate $\backslash$ trading days & 1 & 2 & 3 & 4 & 5 & 6 & 7 & 8 & 9 & 10 \\
\hline EUR/USD & $2 \mathrm{PL}+$ & $\mathrm{N}+$ & $\mathrm{N}+$ & $2 \mathrm{LP}-$ & $\mathrm{C}+$ & $3 \mathrm{~L}-$ & $\mathrm{C}+$ & $2 \mathrm{LP}-$ & $2 \mathrm{LP}-$ & $\mathrm{N}+$ \\
\hline USD/JPY & $\mathrm{C}+$ & $\mathrm{N}+$ & $2 \mathrm{PL}+$ & $2 \mathrm{LP}-$ & $2 \mathrm{PL}+$ & $2 \mathrm{PL}+$ & $\mathrm{C}+$ & $\mathrm{N}+$ & $\mathrm{N}-$ & $\mathrm{N}-$ \\
\hline GBP/USD & $\mathrm{N}+$ & $\mathrm{C}+$ & $2 \mathrm{PL}+$ & $\mathrm{N}+$ & $\mathrm{N}+$ & $2 \mathrm{LP}-$ & $2 \mathrm{PL}+$ & $3 \mathrm{~L}-$ & $\mathrm{N}+$ & $\mathrm{N}+$ \\
\hline GBP/AUD & $2 \mathrm{LP}-$ & $\mathrm{N}+$ & $2 \mathrm{LP}-$ & $\mathrm{C}+$ & $\mathrm{N}+$ & $2 \mathrm{LP}-$ & $\mathrm{N}+$ & $\mathrm{N}+$ & $\mathrm{N}+$ & $\mathrm{N}-$ \\
\hline EUR/JPY & $\mathrm{N}+$ & & $3 \mathrm{P}+$ & $\mathrm{N}+$ & $\mathrm{N}+$ & $\mathrm{N}+$ & $\mathrm{N}+$ & $2 \mathrm{LP}-$ & $\mathrm{N}+$ & $\mathrm{N}+$ \\
\hline USD/CHF & $\mathrm{N}+$ & $2 \mathrm{PL}+$ & $2 \mathrm{PL}+$ & $\mathrm{N}+$ & $\mathrm{N}+$ & $2 \mathrm{LP}-$ & $\mathrm{N}+$ & $\mathrm{N}+$ & $\mathrm{N}+$ & $\mathrm{N}+$ \\
\hline $\mathrm{NZD} / \mathrm{CAD}$ & $2 \mathrm{LP}-$ & $2 \mathrm{LP}-$ & $\mathrm{N}+$ & $2 \mathrm{LP}-$ & $\mathrm{N}+$ & $\mathrm{N}+$ & $\mathrm{N}+$ & $2 \mathrm{LP}-$ & $\mathrm{N}+$ & $\mathrm{N}-$ \\
\hline EUR/GBP & $\mathrm{N}+$ & $\mathrm{N}+$ & $\mathrm{N}+$ & $\mathrm{N}+$ & $\mathrm{N}-$ & $2 \mathrm{LP}-$ & $\mathrm{C}+$ & $\mathrm{N}+$ & $\mathrm{N}-$ & $\mathrm{N}+$ \\
\hline USD/CAD & $\mathrm{C}+$ & $\mathrm{C}+$ & $2 \mathrm{LP}-$ & $\mathrm{N}+$ & $\mathrm{N}+$ & $\mathrm{C}+$ & $2 \mathrm{PL}+$ & $2 \mathrm{LP}-$ & $\mathrm{N}+$ & $\mathrm{N}+$ \\
\hline AUD/USD & $2 \mathrm{LP}-$ & $\mathrm{N}+$ & $3 \mathrm{~L}-$ & $2 \mathrm{PL}+$ & $\mathrm{N}+$ & $\mathrm{N}+$ & $2 \mathrm{PL}+$ & $2 \mathrm{LP}-$ & $\mathrm{N}+$ & $\mathrm{N}+$ \\
\hline
\end{tabular}


Figure 11 presents the comparison of the distributions of the strategies when using different prediction tools based on artificial intelligence. A very big difference exists between the profitable and unprofitable naked strategies: predictions of Keras are more to the right. The covered strategies were more often used when the predictions were made using EVOLINO. Big losses (3L- and 2LP-) were more often a result than big profits $(3 \mathrm{P}+$ and $2 \mathrm{PL}+)$ in both accounts.

a)

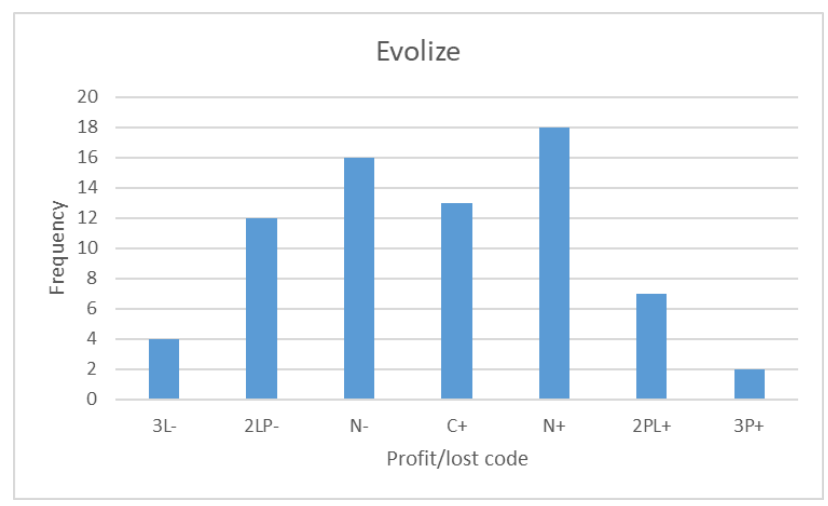

b)

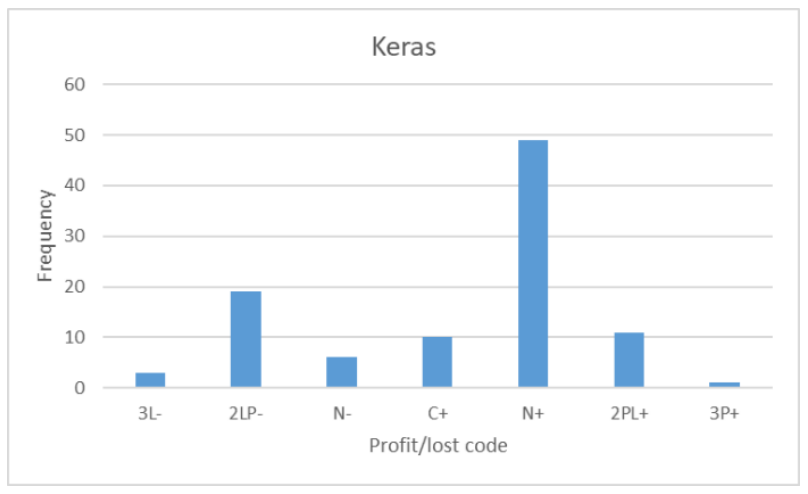

Figure 11. Distributions of strategies: prediction based on a) evolize.com and b) Keras Source: own evaluation.

The valuation of the method of option-trading strategies based on artificial intelligence predictions is presented in Table 3. The comparison of two different prediction tools, both of which have prediction based on distribution, shows that the method can be used in speculation of options. Both tools result in profit (11\% to $13 \%$ profitability), and the number of strategies with profit is more than the number of losses. The Sharpe ratio is not high because the risk of daily trading of an options portfolio is very large. The risk-free rate was selected as the daily treasury yield curve rate during the trading period. 
Valuation of option-trading strategy methods based on artificial intelligence prediction

\begin{tabular}{|l|l|l|}
\hline & Evolize & Keras \\
\hline Number of trades & 72 & 99 \\
\hline Number of exchange rates & 8 & 10 \\
\hline Total profit (euros) & 2237 & 2630 \\
\hline Profitability \% & 11.185 & 13.15 \\
\hline$\%$ of losses & 44 & 28 \\
\hline \% of profits & 56 & 72 \\
\hline max profit & 1830 & 2390 \\
\hline max lost & -3000 & -4000 \\
\hline St. dev. & 3134.25 & 4919.98 \\
\hline$r$ & 1.27 & 1.27 \\
\hline Sharpe ratio & 0.713322 & 0.534297 \\
\hline
\end{tabular}

Artificial intelligence prediction tools are very useful in the very risky option-trading process. Keras computation time is significantly faster than evolize, making it superior to option speculation and can be used for higher frequency speculation. The additional information about forecasted high and low values of exchange rates leads to using all known option strategies with new application possibilities and profitability.

\section{CONCLUSION}

Trading or speculation in the options market is very risky. For successful trading, good skills and selection strategies are needed. Artificial intelligence-based predictions can be useful, such as a support system for the investor. Our article proposed a new method for profitable trading in the options market. The article compared trading using two different tools: evolize.com and the Python deep learning library Keras. Both tools' predictions are a composition of two distributions based on high and low data. Prediction using these tools was integrated into well-known option strategies: naked and covered strategies and strategies based on market sentiments or on a market without a clear direction. A separate case described the trading rules if the prediction is wrong. Trading in real time using 8 to 10 exchange rates every day shows that the proposed method generates profit, at about $11 \%$ to $13 \%$ profitability, and the number of strategies with profit is more than number of strategies with losses. The Sharpe ratio reached 0.53 to 0.72 , although trading in options is very risky (the standard deviation is 3134 to 4920 ).

The main limitation of the investigation is the very short time of trading in real time because of the European Securities and Markets Authority prohibition on binary options. The investigation was started before this limitation, and there was no doubt about the changes in trading conditions in the future. The proposed method is useful for simple options, too, but in a more difficult way. The number of transactions is sufficient for the reliable evaluation of the investigation. The limitations can include the behaviour of investors because the process of selection of the trading strategy is not automatic. 


\section{REFERENCES}

Abadi, M., Agarwal, A., Barham, P., Brevdo, E., Chen, Z., Citro..., \& Zheng, X. (2015). TensorFlow: Large-scale machine learning on heterogeneous systems. arXiv preprint arXiv:1603.04467.

Batta, G.E., Qiu, J., \& Yu, F. (2016). Credit derivatives and analyst behaviour. The Accounting Review, 91(5), 1315-1343.

Bedendo, M., \& Colla, P. (2015). Sovereign and corporate credit risk: Evidence from the Eurozone. Journal of Corporate Finance, 33, 34-52.

Bellalah, M. (2008). Exotic Derivatives and Risk: Theory, Extensions and Applications. Singapore: World Scientific Publishing Co.

Bernal-Ponce, L. A., Castillo-Ramírez, C. E., \& Venegas-Martínez, F. (2020). Impact of exchange rate derivatives on stocks in emerging markets. Journal of Business Economics and Management, 21(2), 610-626. https://doi.org/10.3846/jbem.2020.12220.

Blanco, I., \& Wehrheim, D. (2017). The bright side of financial derivatives: Options trading and firm innovation. Journal of Financial Economics, 125(1), 99-119.

Borg, S. (2015). A critical analysis of the new EU regulatory regime for the OTC derivatives market and its implications on financial markets (Master's thesis, University of Malta).

Bukhari, A. H., Raja, M. A. Z., Sulaiman, M., Islam, S., Shoaib, M., \& Kumam, P. (2020). Fractional neuro-sequential ARFIMA-LSTM for financial market forecasting. IEEE Access, 8, 71326-71338.

Cao, J., Li, Z., \& Li, J. (2019). Financial time series forecasting model based on CEEMDAN and LSTM. Physica A: Statistical Mechanics and its Applications, 519, 127-139.

Cepel, M., Kljucnikov, A., Kozubikova, L., \& Krajcik, V. (2019). LocalCurrency as a Mean of Regional Competitiveness Development. Journal of Competitiveness, 11(4), 22-39. https://doi.org/10.7441/joc.2019.04.02

Civelek, M., Ključnikov, A., Krajčík, V., \& Žufan, J. (2019). The Importance of Discount Rate and Trustfulness of A Local Currency for the Development of Local Tourism. Journal of Tourism and Services, 10(19), 77-92. https://doi.org/10.29036/jots.v10i19.117

Chang, K.C., \& Tian, Z. (2015, July). Market analysis and trading strategies with Bayesian networks. In Information Fusion (Fusion), 2015 18th International Conference on (pp. 1922-1929). IEEE.

Chollet, F. (2018). Keras: The python deep learning library. Astrophysics Source Code Library. https://keras.io

Chung, C.Y., Kim, H., \& Ryu, D. (2017). Foreign investor trading and information asymmetry: Evidence from a leading emerging market. Applied Economics Letters, 24(8), 540-544.

DaDalt, P., Gay, G.D., \& Nam, J. (2002). Asymmetric information and corporate derivatives use. Journal of Futures Markets: Futures, Options, and Other Derivative Products, 22(3), 241-267.

Danielsson, J., James, K.R., Valenzuela, M., \& Zer, I. (2016). Model risk of risk models. Journal of Financial Stability, 23, 79-91.

Duffee, G.R. \& Zhou, C. (2001). Credit derivatives in banking: Useful tools for managing risk?. Journal of Monetary Economics, 48(1), 25-54.

D’Errico, M., Battiston, S., Peltonen, T., \& Scheicher, M. (2018). How does risk flow in the credit default swap market? Journal of Financial Stability, 35, 53-74.

Froot, K.A., Scharfstein, D.S., \& Stein, J.C. (1993). Risk management: Coordinating corporate investment and financing policies. The Journal of Finance, 48(5), 1629-1658.

Godwin, A., Ramsay, I., \& Sayes, E. (2017). Assessing financial regulatory coordination and integration with reference to OTC derivatives regulation. Capital Markets Law Journal, 12(1), 38-65.

Harada, K., Hoshi, T., Imai, M., Koibuchi, S., \& Yasuda, A. (2016). Japan's financial regulatory responses to the global financial crisis. In The First Great Financial Crisis of the 21st Century: A Retrospective (145-166).

Hochreiter, S., \&Schmidhuber, J. (1997). Long short-term memory. Neural computation, 9(8), 1735-1780. DOI=http://dx.doi.org/10.1162/neco.1997.9.8.1735

Huang, S.C. (2008). Online option price forecasting by using unscented Kalman filters and support vector machines. Expert Systems with Applications, 34(4), 2819-2825.

Instefjord, N. (2005). Risk and hedging: Do credit derivatives increase bank risk? Journal of Banking \&Finance, 29(2), 333-345.

Jarrow, R.A. (2018). Incomplete Markets. In Continuous-Time Asset Pricing Theory (pp. 151-156). Springer, Cham. 
Junges, L., \& Gallas, J.A.C. (2012). Intricate routes to chaos in the Mackey-Glass delayed feedback system, Physics Letters $A$ 376, 2109-2116.

Kao, Y.S., Zhao, K., Ku, Y.C., \& Nieh, C.C. (2019). The asymmetric contagion effect from the U.S. stock market around the subprime crisis between 2007 and 2010, Economic Research-Ekonomska Istraživanja, 32(1), 2422-2454, https://doi.org/10.1080/1331677X.2019.1645710

King, A.J., Streltchenko, O., \& Yesha, Y. (2005). Using multi-agent simulation to understand trading dynamics of a derivatives market. Annals of Mathematics and Artificial Intelligence, 44(3), 233-253.

Kingma, D., \& Ba, J. (2015). Adam: A Method for Stochastic Optimization, ICLR, arXiv preprint arXiv:1412.6980.

Kotaskova, A., Belas, J., Bilan, Y., \& Khan, K. A. (2020). Significant Aspects of Managing Personnel Risk in the SME Sector. Management \& Marketing, 15(2), 203-218.

Kozarevic, E., \& Jukan, M.K. (2011). Derivatives market development in Bosnia and Herzegovina: Present or (far) future? International Journal of Management Cases, 13(3), 637-646.

Lange, J., \& Longitude L.L.C. (2011). Digital options having demand-based, adjustable returns, and trading exchange therefor. U.S. Patent 7,996,296.

Le Grand, F., \& Ragot, X. (2016). Incomplete markets and derivative assets. Economic Theory, 62(3), 517-545.

Li, X., Subrahmanyam, A., \& Yang, X. (2018). Winners, Losers, and Regulators in a Nascent Derivatives Market: Evidence from Chinese Brokerage Data. Available at SSRN https://ssrn.com/abstract=3115973.

Livieris, I. E., Pintelas, E., \& Pintelas, P. (2020). A CNN-LSTM model for gold price time-series forecasting. Neural Computing and Applications, 1-10.

Maknickienė, N. \& Maknickas, A. (2016). Prediction Capabilities of Evolino RNN Ensembles. In Computational Intelligence (pp. 473-485). Springer, Cham.

Maknickas, A. \& Maknickienè, N. (2019). Support System for Trading in Exchange Market by Distributional Forecasting Model. Informatica, 30(1), 73-90.

Mentel, G., Szetela, B., \& Tvaronavičienė, M. (2016), Qualifications of Managers vs. Effectiveness of Investment Funds in Poland, Economics and Sociology, 9(2), 126-136. DOI: 10.14254/2071-789X.2016/9-2/8

Mentel, G., Brożyna, J., \& Szetela, B. (2017). Evaluation of the effectiveness of investment fund deposits in Poland in a time of crisis. Journal of International Studies, 10(2), 46-60. doi:10.14254/2071-8330.2017/10-2/3

Meyer, R. (2017). Profitability patterns in the interest rate derivatives market. Review of Derivatives Research, 20(3), 231254.

Muck, M. (2010). Trading strategies with partial access to the derivatives market. Journal of Banking \& Finance, 34(6), 1288-1298.

Munkhdalai, L., Li, M., Theera-Umpon, N., Auephanwiriyakul, S., \& Ryu, K. H. (2020, March). VAR-GRU: A Hybrid Model for Multivariate Financial Time Series Prediction. In Asian Conference on Intelligent Information and Database Systems (pp. 322-332). Springer, Cham.

Neal, R.S. (1996). Credit derivatives: New financial instruments for controlling credit risk. Economic Review-Federal Reserve Bank of Kansas City, 81, 15-28.

Schmidhuber, J., Wierstra, D., \& Gomez, F.J. (2005). Evolino: Hybrid neuroevolution/optimal linear search for sequence prediction. In Proceedings of the 19th International Joint Conference on Artificial Intelligence (IJCAI).

Stankevičiené, J., Maknickienè, N., \& Maknickas, A. (2014). May. Investigation of exchange market prediction model based on high low daily data. In The 8th International Scientific Conference Business and Management 2014 (pp. 15-16).

Šestanović, T., Arnerić, J., \& Aljinović, Z. (2018). Non-structural approach to implied moments extraction, Economic Research-Ekonomska Istraživanja, 31(1), 1923-1939, https://doi.org/10.1080/1331677X.2018.1530607

Štefko, R., Jenčová, S., \& Vašaničová, P. (2020). The Slovak Spa Industry and Spa Companies: Financial and Economic Situation. Journal of Tourism and Services, 20(11), 28-43. doi: 10.29036/jots.v11i20.137

Tan, C. (2010). Demystifying Exotic Products: Interest Rates, Equities and Foreign Exchange. New York: John Wiley \& Sons.

Thapa, C., Neupane, S., \& Marshall, A. (2016). Market liquidity risks of foreign exchange derivatives and cross-country equity portfolio allocations. Journal of Multinational Financial Management, 34, 46-64.

Trang, K. H. (2018). Financial derivatives use and multifaceted exposures. Journal of Asian Business and Economic Studies, 25(1), 86-108. Retrieved from https://doi.org/10.1108/JABES-04-2018-0004 
Ucar, I., Ozbayoglu, A.M., \& Ucar, M. (2015, May). Developing a two level options trading strategy based on option pair optimization of spread strategies with evolutionary algorithms. In Evolutionary Computation (CEC), 2015 IEEE Congress on (pp. 2526-2531). IEEE.

Vashishtha, A., \& Kumar, S. (2010). Development of financial derivatives market in India: A case study. International Research Journal of Finance and Economics, 37(37), 15-29.

Vo, D.H., Huynh, S.V., Vo, A.T., \& Ha, D.-T. (2019). The Importance of the Financial Derivatives Markets to Economic Development in the World's Four Major Economies. Journal Risk Financial Management. 12(1), 35, https://doi.org/10.3390/jrfm12010035.

Wu, H.C. (2004). Pricing European options based on the fuzzy pattern of Black-Scholes formula. Computers \& Operations Research, 31(7), 1069-1081.

Wu, W., Wang, Y., Fu, J., Yan, J., Wang, Z., Liu, J., ... \& Wang, X. (2019, September). Preliminary Study on Interpreting Stock Price Forecasting Based on Tree Regularization of GRU. In International Conference of Pioneering Computer Scientists, Engineers and Educators (pp. 476-487). Springer, Singapore.

Wu, X., Xie, H., \& Li, X. (2019). Probability weighting functions obtained from Hong Kong index option market, Economic Research-Ekonomska Istrą̌ivanja, 32(1), 1922-1943, https://doi.org/10.1080/1331677X.2019.1638285

Wu, X., Zhou, H., \& Wang, S. (2018). Estimation of market prices of risks in the G.A.R.C.H. diffusion model, Economic Research-Ekonomska Istraživanja, 31(1), 15-36, https://doi.org/10.1080/1331677X.2017.1421989

Yamak, P. T., Yujian, L., \& Gadosey, P. K. (2019, December). A Comparison between ARIMA, LSTM, and GRU for Time Series Forecasting. In Proceedings of the 2019 2nd International Conference on Algorithms, Computing and Artificial Intelligence (pp. 49-55).

Yang, Y., Zheng, Y., \& Hospedales, T.M. (2017, February 10). Gated Neural Networks for Option Pricing: Rationality by Design. In $A A A I$ (The Thirty-First AAAI Conference on Artificial Intelligence) (pp. 52-58).

Yao, J., Li, Y., \& Tan, C.L. (2000). Option price forecasting using neural networks. Omega, 28(4), 455-466.

Zelenko, I., (2017). Credit Risk Management for Derivatives: Post-Crisis Metrics for End-Users. Springer. 